\title{
MODEL FOR IMPLEMENTING SUCCESSFUL CUSTOMER RELATIONSHIP MANAGEMENT IN SAUDI TELECOM INDUSTRY
}

\author{
Sara AL-Rashed ${ }^{1}$ and Dr.Riyad Almakki ${ }^{2}$ \\ ${ }^{1}$ Department of Information system, AL-Imam Muhammad bn Saud Islamic University, \\ Riyadh City, Saudi Arabia \\ ${ }^{2}$ Depatrment of Information system, AL-Imam Muhammad bn Saud Islamic University, \\ Riyadh City, Saudi Arabia
}

\begin{abstract}
The telecommunications sector in Saudi Arabia is continuously seeking to a close relationship with their customers. Most telecom companies have Customer Relationship Management (CRM) system. However, implementing CRM systems have a low success rate. This paper aims to propose a model that helps the telecom companies to increase the level of implementing successful CRM system. A model is drawn to identify the critical success factors that contribute to successful CRM system in Saudi telecommunication sector. Seven basic hypotheses were tested, as parts of a theoretical model of successful CRM system. Data was collected through a questionnaire. The empirical analysis was carried out using a structural equation model and regression. In addition, follow-up interviews were conducted with a small number of top managers. Data obtained from the questionnaire was triangulated with data gathered from follow-up interviews. The findings revealed that the seven hypotheses were supported and lead to CRM success.
\end{abstract}

\section{KEYWORDS}

CRM, Critical success factors, Technology, Knowledge management.

\section{INTRODUCTION}

The telecommunications industry in Saudi Arabia is seeking to develop close relationships with the companies' customers. Today, many telecom companies are rushing to develop their products and services in the form of customer centres. Telecom companies are meeting the competition by striving to improve their communication with customers by investing and implementing Customer Relationship Management (CRM) [1]. The CRM system as a tool can help telecom companies to accomplish an alteration of goals. CRM, which is considered a tool for improving the competitive advantage, enables the telecommunication industry to better understand their customers' requirements. In addition, it facilitates a better understanding of the customer's behaviour [1]. From reference [2] perspective, CRM is a strategy as well as a learning process that includes people, processes, and technology. While reference [3] defined CRM as a process, strategy, philosophy, capability, or a technological tool. Despite variations in specific conceptualizations, these definitions suggest that CRM is crucially important for every company functioning since it involves gaining customers' loyalty through marketing, placing emphasis on technology as a way of enhancing the company's success.

CRM can contribute to improving customer responsiveness, growing revenue and helping a company to capture a competitive advantage. However, while both the success and failure rates of CRM implementation are described in the existing literature, a high failure rate is associated with 
the implementation of CRM systems [4], [5]. Reference [5] estimated around 70\% of all CRM projects resulted in failure.

Clearly, CRM systems have encountered high rates of failure. The process of integrating CRM into a company is a complex one, and the potential problems that arise must be properly managed for a CRM system to achieve its desired results. Successful CRM systems depend strongly on the identification and employment of critical success factors (CSFs). The presented study aimed to overcome this problem by building successful CRM system model in the telecom industry of Saudi Arabia. This model will bridge the gap of failure in CRM system and provide a useful guide for successful CRM system. Thus, the contribution of this paper is the proposal of an integrated model of factors affecting CRM success in Saudi Arabia.

\section{LITERATURE REVIEW}

\subsection{Successful CRM System}

The successful implementation of a CRM system can provide a critical role in an organization's tactical position. CRM success assists in keeping customers and makes them more loyal. Particularly, the successful implementation of a CRM system will benefit organizations by enhancing customer profitability and attracting additional consumers [6]. The first critical goal during the development of a CRM platform is to identify a company's definition of CRM success [7]. Reference [6] observed that the implementation of a CRM system is considered successful when it assists its company in meeting its business goals. These may involve multiple and varied goals, consisting of marketing goals, such as the loyalty, retention, acquisition, and satisfaction of customers, and financial goals, such as increased profits and reduced costs.

Customer satisfaction can be defined as a customer's response or feeling of satisfaction toward the experience of using a company's products or services. Various researchers [4], [8], [9] have used customer satisfaction as a measure of CRM system success. According to studies by [4], [8], [9] customer loyalty can also be used to measure the success of CRM system. Customer loyalty is a client's continuous belief that one organization's services or products are better than the services or products that are offered by other organizations. Loyalty is primarily related to company performance and represents a customer's belief that a corporation will offer them the correct services or products at the right time, place, and price [10]. Profitability represents the deduction of organizations from the whole revenues and the offer of services or goods for their customers over a specific time period [11]. Finally, the successful CRM system will benefit organizations based on increasing their profitable customers [4].

\subsection{Critical Success Factors (CSFs):}

Successful CRM systems depend strongly on the identification and employment of critical success factors (CSFs). Frist the definition of CSFs will be described and then the factors will be discussed. CSFs can be defined as the areas where objects must be corrected before a business can grow and flourish [6]. Reference [12] say, "Critical success factors for CRM are the limited number of areas that must achieve satisfactory results to make CRM implementation a success.'. Before the identification of CRM system, it is vital to clarify what does a success factor mean. Success factors can be defined as a set of components that stand for specific aims, which if obtained, can ensure the satisfactory outcome of a CRM system [13].

In the presented study, the researcher believes through an extensive review of the literature about the CSFs of CRM system. Several previous studies have discussed the factors that contribute to the successful enabling of CRM platforms, which have received increasing attention over time 
within CRM literature. In this study, successful CRM system implementation model was developed based on seven factors mentioned in the literature: knowledge management, top management support, training, CRM vision, reward system, technology, and business process reengineering and integration.

\subsubsection{Knowledge Management(KM)}

Generally, knowledge is an essential variable and is a source of competitive advantage for an organization. As such, it has an essential role in the success of modern businesses. Knowledge management $(\mathrm{KM})$ is a main research concern within the academic community as well, as it is considered one of the main factors for which companies allocate extra financial resources. Knowledge management permits organizations to access the specialized experiences and knowledge of employees to make improvements, generate new capabilities and enhance functional efficiency [14].

Knowledge management includes the generation of new knowledge produced following the explanation, distribution, and use of existing knowledge, as well as the conservation and modification of existing knowledge. Knowledge management is a goal of any organization seeking to generate and enhance its knowledge resources. It mainly requires the related activities of the association, identification, and generation of knowledge. The success of any organization thus depends on creating and developing knowledge resources [4]. Knowledge management can be defined as a company's ability to capture, manage and deliver valid, real-time product and service information with the goals of enhancing customer response and enabling faster decisionmaking based on reliable, real-time and accurate information [12]. KM is one of the major interests of the contemporary corporate culture worldwide, and many companies have incorporated knowledge management into their plans. CRM systems should manage knowledge related to customers with the goals of improving service to and increasing the corporate understanding of clients [15]. Likewise, [4] explained that a CRM system is related to the elements of knowledge management. Therefore, efficient and continuously updated knowledge about customers is vital to the successful introduction of CRM systems. Customer knowledge is highly valuable to both companies and their CRM systems [4]. Even though research is limited to the detailed association of knowledge management with successful CRM systems especially in Saudi Arabia, the exploration of the following hypothesis may produce useful information for resolving this issue. Therefore, the researcher has proposed the following:

\section{H1. Knowledge management significantly and positively associated with successful CRM system.}

\subsubsection{Top Management Support}

Generally, the support of top managers is an essential variable and a source of competitive advantage to an organization. As such, it has an essential role in the success of modern businesses. This factor involves the motivation of top management to offer important resources needed in the implementation process. Top management support represents the acceptance of CRM as the main business strategy that enables organizations to build good relationships with their customers. This support can facilitate the design of an effective CRM system, which requires adequate resources. Such resources cannot be obtained or sustained without support from high-level management. The degree to which top managers are motivated affects both the success of CRM program implementation and its specific strategies.

Many academics and researchers have explored the role of top management support in successful CRM implementation [6], [9], [10]. Reference [16] executed a study that examined the influences of CRM on customer loyalty in the telecom industry in Iran. The researchers gathered information 
from 200 users of Iranian telecom services. The results showed that the support and commitment of corporate managers were critical and required for implementing a successful CRM system. These findings were consistent with those of [4] who also found the support of top managers was positively linked to CRM implementation success.

Reference [8] mentioned that support from management can be in the form of providing sufficient resources and establishing clear objectives with respect to CRM implementation. To achieve successful CRM implementation, top managers need to be informed about the process and goals of CRM, allocate adequate resources for the related tasks and ensure all involved employees understand the CRM program objectives. The top managers also need to encourage and ensure strong corroboration and collaboration among staff [10].

Although research is limited to the specific impact of top management support on Successful CRM Systems in Saudi Arabia, exploration of the following hypothesis may produce useful information to resolve this issue. Therefore, the researcher has proposed the following:

H2. Top management support significantly and positively associated with successful CRM system.

\subsubsection{Training}

The training factor represents the availability of qualified employees to provide customer service training to other employees and the organization's ability to offer effective training programs. Employee training represents the description and arrangement of training courses, which can be helpful when implementing a CRM system because training can help ensure the success of the system. The training stage must be performed at the beginning of CRM implementation. With training, employees can fully understand the positive effects of CRM in providing enhanced services and products for customers. In addition, enhance their knowledge and improve their skills [17].

The training factor is considered in this work because it is important to investigate the relationship between this variable and CRM success.

\section{H3. Training significantly and positively associated with successful CRM system.}

\subsubsection{CRM Visions}

The When implementing a CRM system, vision plays a critical role, as it allows stakeholders to communicate and share an interpretation of the system's essential features. CRM vision can be defined as the personality of any organization; vision creates a clear image for customers concerning company products, services, and offers. The vision represents how the business wants its customers to feel and think about it [18]. Reference [19] CRM implementation sometimes fails because ambiguity in the CRM vision exists; the plan for introducing and managing the system is not clear or well considered. For a CRM system to succeed, top managers need a strong, defined CRM vision and need to share it with employees, thereby encouraging them to activate their own CRM vision [4]. CRM vision is a variable explored in this study. Therefore, the researcher has proposed the following:

\section{H4. CRM vision significantly and positively associated with successful CRM system.}

\subsubsection{Reward System}

The Rewards can be considered one of the main factors facilitating the development of deep 
customer knowledge in a CRM system. Organizations should structure performance-dependent rewards to motivate their employees, which in turn should enhance their performance and customers' satisfaction. Employee rewards can be defined as the acknowledgment of employee work in light of a company`s values. CRM rewards highlight the significance of changes in communication and values within an organization, thereby helping ensure all staff recognizes the significance of customer-centric performance as they attempt to generate strong customer's relations [17], [20]. Reward systems are considered in this work because it is important to investigate the relationship between this factor and CRM system success.

\section{H5. Reward system significantly and positively associated with successful CRM system.}

\subsubsection{Technology}

Managers know that customers are at the centre of business and that the success of their companies depends on them. Since telecommunication companies generally have large customer bases, it can be a challenge for these companies to ensure individual customer satisfaction. Loyal customers expect the best service, and ideally, technology can meet this challenge. However, if a company lacks an appropriate infrastructure, technology can present a major obstacle to the implementation of CRM systems. Several studies, including [8], [10], [21] have mentioned that when technology is used incorrectly, CRM systems are more likely to fail.

The technology factor represents a collection of corporate resources that permit an organization to save, utilize, collect and organize data about its customers [22]. Effective technology enables employees who engage with CRM systems to save, gather and categories important data for and about their customers. By using information technology (IT), which offers an enhanced view of customer performance, organizations can develop enhanced relationships with their customers [22]. Technology can support CRM systems in diverse ways. For instance, it can aid in the identification of customer behaviour and streamline the collection, processing, and management of customer data [10]. Furthermore, the use of appropriate technology can facilitate communication between customers and companies, resulting in the development of new working methods and increased customer satisfaction. As mentioned earlier, technology can also be used to conduct statistical analyses that effectively leverage operational efforts to invest in CRM [10].

Technology within a CRM system should first be activated by generating a customer database that comprises an infrastructure of customer information; this process can help to facilitate the overall development of the CRM framework. Numerous technologies can be used during the development of CRM systems, such as data mining, analytical processing and data warehouse querying and reporting. Data mining provides a vital role in the implementation of CRM systems since it allows employees to efficiently collect and identify data related to customer relationship [4]. Data warehousing's role is similarly significant because it enables customer data to be merged, managed, correlated and transformed into forms and formats that allow for the easy analysis and identification of customer behaviour. By using technology, a company can combine its customer information into an up-to-date and comprehensive database [17]. Given that technology is regarded as one of the main components of CRM system [21], the role of technology is widely accepted in the literature, and technology issues have been reported as being among the causes of CRM failure [10]. Technology is a variable explored in this study. Therefore, the researcher has proposed the following:

\section{H6. The technology significantly and positively associated with successful CRM system.}

\subsubsection{Business Process Re-engineering and Integration}

Cross-functional integration refers to the practice in which employees, business processes, and 
information from two or more departments are brought together to complete a company task or goal [23]. Integration is an essential feature in CRM systems, as it converts the outputs of value generation and business strategy processes into value-adding activities for customers. It is also completely dependent on an organization's ability to collect customer information and then integrate it with other related data [9], [10].

During the implementation of a CRM program, established practices and processes must change. This means that targeted systems must be re-engineered to align with a customer-focused approach [21]. For an effective CRM system to be executed across an entire company, that company must first connect its various processes and departments. These processes also require change [21].

Business process re-engineering involves changes to present and current business processes and the implementation of new ones. These new processes occur by rethinking and redesigning current business practices to gain considerable improvements in significant, modern performance measures. The business process re-engineering and integration factor is explored in this study because it has wide acceptance as important in the research field and because poor management of process changes is considered a factor in CRM systems failures [4], [20], [21].

H7: Re-engineering and integration process is significantly and positively associated with successful CRM system.

\section{RESEARCH MODEL}

The initial model is developed by researcher and will serve as the basis to overcome the high failure of CRM system. The researcher called this model the Maturity Successful CRM Implementation model (MSCRMI). This framework represents the independent variables of knowledge management, top management support, training, CRM vision, reward system, technology, and business process re-engineering and integration, and includes the dependent variable, CRM implementation success in the telecommunication sector in Saudi Arabia as shown in Figure 1.

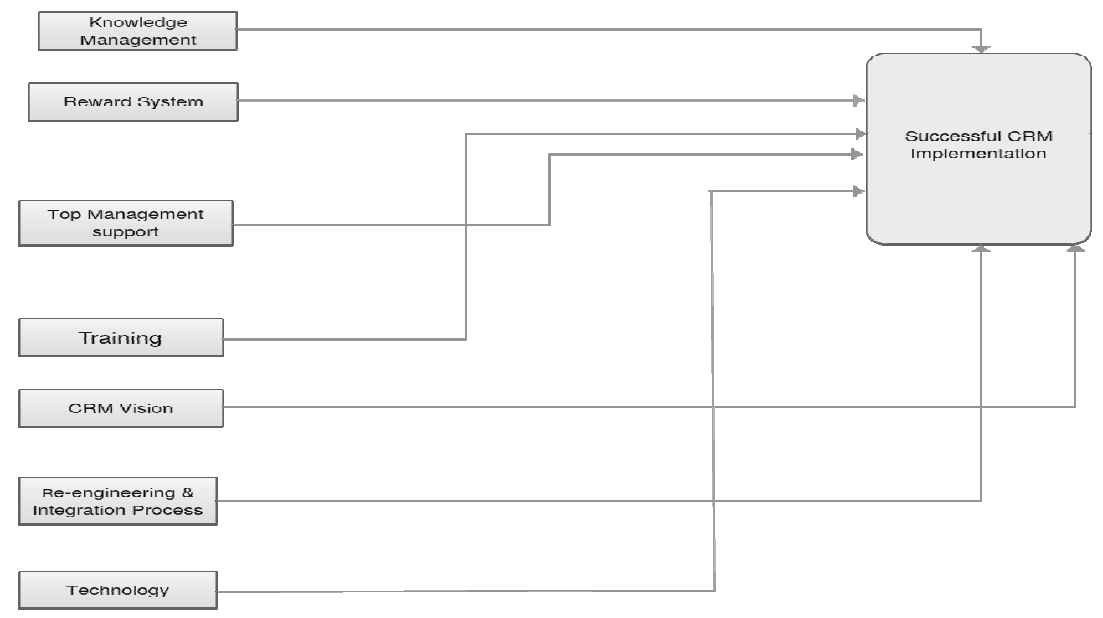

Figure 1. The MSCRMI theoretical framework. 
International Journal of Business Information Systems Strategies (IJBISS) Vol.7, No.1, February 2018

\section{Methodology}

Triangulation is proposed to be used for this study. Triangulation means looking at something from multiple points of view to increase and expand accuracy. Triangulation is defined as the use of multiple methods mostly qualitative and quantitative techniques in studying the same phenomenon for the determination of enhancing research credibility [24].

There are several aims for using triangulation. One of the aims of using the triangulation is to enhance the credibility, accuracy, and validity of the research results through merging two research methods (survey and interview). Furthermore, reference [25] referred that a triangulation method generates better chances to assess the extent to which the research results can be reliable, accurate, validate, and trusted. Moreover, using triangulation allow researchers to be further confident of their results.

In the presented research, the researcher uses the survey (quantitate method) to answer questions that targeted the employees and branch's managers. However, the interview (qualitative method) used to answer questions that targeted leaders which can confirm or contradict the result from the survey as well as complement the research findings (empirical contribution). Thus, the collecting and analysing of data is in sequence: survey collecting from employees and managers then interview collecting from leaders.

\subsection{Survey}

This study chose a systematic random sample in which 230 respondents were identified from 30 places in the communication sector in the middle region of Saudi Arabia. The sampling frame for this study consisted of employees and branch`s managers who worked with CRM system and interact with customers in the communication sector in Saudi Arabia. Out of the 230 questionnaires distributed, 27 were undelivered, and nine questionnaires were incomplete (missing responses). Thus, a total of 194 responses were usable and used for subsequent analysis, giving a response rate of $84.3 \%$.

The questionnaire is divided into: (1) demographic variables (one item); (2) CRM vision (three items) adapted by [4], [21]; (3) knowledge management (seven items) adapted by [4], [17]; (4) top management support (four items) by [4], [20]; (5) training (four items) by [4], [5], [9]; (6) Reward system (four items) by [4], [20], [21];(7) business process re-engineering and integration (five items) by[4], [23], [21], [9]; (8) technology (six items) by [4], [17]; and (9) successful CRM systems (four items) by [4], [17].

\subsubsection{Demographic Profile of the Respondents}

The research population is all employees and branch managers in the main telecom companies (STC, Mobily, and Zain) branches at Riyadh, Saudi Arabia. The sample for this research is mainly based on random sampling. There are 30 main branches. 50\% of these branches were selected randomly which mean 16 main branches. In the process of conducting the main study, 230 questionnaires were distributed to collect data using a survey. Out of this number,27 were undelivered, and 9 questionnaires were incomplete (missing responses). Thus, 194 responses were usable for subsequent analysis, the response rate is $84.3 \%$. The following table, Table 1 , features the characteristics of the survey sample according to the job title. Based on Table 1, 194 participants of the sample study, representing a rate of $91.2 \%$, were employees, who constituted the largest group of the study sample, while 17 of the participants, representing a rate of $8.8 \%$, were managers, who made up the smallest category of the study sample. 
International Journal of Business Information Systems Strategies (IJBISS) Vol.7, No.1, February 2018

Table 1. The Distribution of Respondents

\begin{tabular}{|c|c|c|}
\hline Current Position & Frequency & Percent \\
\hline Employee & 177 & $91.2 \%$ \\
\hline Manager & 17 & $8.8 \%$ \\
\hline Total & 194 & $100 \%$ \\
\hline
\end{tabular}

\subsubsection{Reliability Test}

The research framework consists of seven independent variables (knowledge management, top management support, training, CRM vision, reward system, technology, and business process reengineering and integration) and one dependent variable (successful CRM systems) (see Table 2). Each construct shows Cronbach alpha readings of acceptable values of above 0.70 [26]. The reliability values for all constructs range from .826 to .964 . This indicates that all constructs have acceptable internal consistency.

Table 2. The Cronbach Alpha Test

\begin{tabular}{|l|l|l|l|}
\hline \multicolumn{1}{|c|}{ Construct } & $\begin{array}{l}\text { Original } \\
\text { Items }\end{array}$ & $\begin{array}{l}\text { Items } \\
\text { after } \\
\text { CFA }\end{array}$ & $\begin{array}{l}\text { Cronbach } \\
\text { Alpha after } \\
\text { CFA }\end{array}$ \\
\hline knowledge management & 7 & 7 & .905 \\
\hline Top management support & 4 & 4 & .921 \\
\hline Training & 4 & 4 & .915 \\
\hline CRM vision & 3 & 3 & .904 \\
\hline Reward system & 4 & 4 & .903 \\
\hline $\begin{array}{l}\text { Business process Re-engineering and } \\
\text { Integration }\end{array}$ & 5 & 3 & .923 \\
\hline Technology & & & \\
\hline Successful CRM Systems & 6 & 5 & .964 \\
\hline
\end{tabular}

\subsubsection{Confirmatory Factor Analysis (CFA)}

Table 3 shows that the confirmatory factor analysis (CFA) results. The researcher observed that the factor loadings of all observed variables or items are adequate, ranging from 0.674 to 0.976 . In this study, the 'cut-off' point chosen for significant loading is 0.50 , the minimum level required for a sample size of 120 and above as suggested by [26].

This indicates that all the constructs conform to the construct validity test. As shown in Table 3, the total of remaining items is 33 . 
International Journal of Business Information Systems Strategies (IJBISS) Vol.7, No.1, February 2018

Table 3. Final CFA Results of Construct Variables

\begin{tabular}{|l|l|l|}
\hline Variable Name & $\begin{array}{c}\text { Items } \\
\text { after } \\
\text { CFA }\end{array}$ & $\begin{array}{c}\text { Estimate } \\
\text { (Factor } \\
\text { Loading) }\end{array}$ \\
\hline Knowledge management & KM7 & .711 \\
\hline Knowledge management & KM6 & .791 \\
\hline Knowledge management & KM5 & .743 \\
\hline Knowledge management & KM4 & .806 \\
\hline Knowledge management & KM3 & .855 \\
\hline Knowledge management & KM2 & .674 \\
\hline Knowledge management & KM1 & .745 \\
\hline Top management support & TOP4 & .886 \\
\hline Top management support & TOP3 & .897 \\
\hline Top management support & TOP2 & .817 \\
\hline Top management support & TOP1 & .851 \\
\hline Training & TR4 & .782 \\
\hline Training & TR3 & .870 \\
\hline Training & TR2 & .932 \\
\hline Training & TR1 & .811 \\
\hline CRM vision & VS3 & .835 \\
\hline CRM vision & VS2 & .949 \\
\hline CRM vision & VS1 & .841 \\
\hline Rewarding system & RS4 & .826 \\
\hline Rewarding system & RS3 & .861 \\
\hline Rewarding system & RS2 & .836 \\
\hline Rewarding system & RS1 & .834 \\
\hline Technology & TCH5 & .848 \\
\hline Technology & TCH4 & .906 \\
\hline Technology & TCH3 & .968 \\
\hline Technology & TCH2 & .958 \\
\hline Technology & TCH1 & .911 \\
\hline Re-engineering and integration process & RIP3 & .934 \\
\hline Re-engineering and integration process & RIP2 & .976 \\
\hline Re-engineering and integration process & RIP1 & .778 \\
\hline CRM success & SUC3 & .718 \\
\hline CRM success & SUC2 & .844 \\
\hline CRM success & $\mathbf{3 3}$ & \\
\hline Total Items Remaining & & \\
\hline
\end{tabular}

\subsubsection{Hypotheses Results}

The number as shown in Table 4 hypothesized model did achieve model fit $(\mathrm{p}<.01)$. Hence, the explanation of the hypothesis result is based on Multiple Regression Test result by SPSS version 
23. Based on the finding, shown in Table 4, seven hypotheses are significant through $t$ values and are acceptable because the value of $t$ is above $+/-1.96$ and the model fit all seven factors. According to the multiple regression test (particularly adjusted $\mathrm{R}$ square), all factors together impact increase the success of CRM system $65.1 \%$.

Table 4. Multiple Regression Analysis Test of the Model

\begin{tabular}{|l|l|l|l|l|l|}
\hline H & $\begin{array}{c}\text { Regression } \\
\text { weights from }\end{array}$ & To & $\begin{array}{c}\text { Standard } \\
\text { Error } \\
\text { (SE) }\end{array}$ & t & sig \\
\hline H1 & KM & suc & .05 & 5.756 & .000 \\
\hline H2 & TOP & suc & .04 & 2.868 & .005 \\
\hline H3 & TR & suc & .04 & 2.704 & .007 \\
\hline H4 & VS & suc & .03 & 2.916 & .004 \\
\hline H5 & RS & suc & .04 & 3.569 & .000 \\
\hline H6 & TCH & suc & .03 & 3.273 & .001 \\
\hline H7 & RIP & suc & .03 & 2.633 & .009 \\
\hline
\end{tabular}

\subsection{Interview}

The researcher suggested follow-up semi-structured interviews as a secondary data collection technique. Based on the review of previous studies [4], [21], [8] as well as the research survey, the interview questions were designed. The research sample includes three main telecommunication companies in Saudi Arabia (STC, Mobily, and Zain). The sample includes seiner managers from these companies.

In the semi-structured interviews, the researcher used qualitative data collection to examine and confirm the findings (extracted by survey) in more detail and to provide more understanding of CRM system. Furthermore, to see whether the opinions and views of seiner manager matching (confirm) or dis-matching the employees' view. That helped the researcher to investigate the impact of CRM system success.

Furthermore, in the interviews, participants were asked to support and confirm or reject the study done previously. Additionally, the interview contributors were encouraged to provide their own views and suggestions with respect to CRM success.

\subsubsection{Analysing the Interview Results}

For analysing and reporting the data that the researcher has obtained from the interviews, the content analysis method is used. In general, the interviewees have been very helpful and cooperative. For the current study, seven main categories were built: knowledge management; top management; training; CRM vision; reward system; technology; business process re-engineering and integration. Below each category, the interviewees made several comments.

KM has a strong impact on CRM success one of the managers in company B remarked: "KM has a strong effect. You can determine and know all customers' information and their needs from $K M$ ". At company $\mathrm{C}$, a manager pointed out that $\mathrm{KM}$ has strong effect " $\mathrm{Km}$ has a strong effect, the company success depends on studying customers' needs that can be stored in, and extract from $K M$ “.

The technology was found to be an influential success factor in all companies (A, B, C). One of the respondents at company A claimed:" Technology is the critical element that helps in reducing 
International Journal of Business Information Systems Strategies (IJBISS) Vol.7, No.1, February 2018

the time for employees in storing, analysing, extracting and identifying customer's information". Furthermore, Manager in Company $\mathrm{C}$ commented:" technology is the interface and backbone of the CRM system."

Top management support had a strong effect on success CRM system in all three companies (A, $\mathrm{B}, \mathrm{C}$ ). Interviewees revealed that managers had joined actively in the CRM system, allocating the requirements. In company B a manager claimed: " Top management support is a critical factor for both employees and customers and has a strong effect on CRM system success".

The training factor was explained by the respondents of the interview. A manager at company B commented: "Training has a strong effect especially in developing employees' skills and acquiring new ones as well as enable the employees to look and explore the experiences of others".

Additionally, most of the interviewees stated that the CRM vision strongly impacts the CRM system success. A manager from company $\mathrm{C}$ stated, "Our vision is expecting future customer needs".

The Reward system factor was explained by the respondents of the interview. From C company, a manager commented: "rewarding is one of the main elements that had an impact on CRM system. In fact, rewarding is a clear, and strong impact".

Business process re-engineering and integration factor was found to be an influential success factor in all companies (A, B, C). One of the respondents at company C claimed:" In our company, processes have to be changed based on customer's needs and technology developments".

\section{DISCUSSION}

The empirical evidence for the first hypothesis knowledge management has proved that there is a positive relationship between KM and CRM success system registered the greatest and the most significant standardized beta coefficient, indicating $44.7 \%$. Furthermore, KM is the most important predictor of successful CRM system. The results tend to agree with the finding of studies by [4], [12], [8]. The follow-up interview findings are consistent with the study suggestion regarding that KM has a positive impact on CRM system success. In general, the interviewees indicate that $\mathrm{Km}$ has a strong impact on CRM success system. This implies that Saudi telecom companies should pay more attention to KM features to be able to reach a higher level of CRM success.

The empirical evidence has proved that there is a positive relationship between technology and CRM success system registered the second greatest and significant standardized beta coefficient, indicating $34.1 \%$ technology positively increase the success of CRM. Therefore, the presented result provides support for the result put forward by [4], [17], [8]. Additionally, the participants of the follow-up interviews enhance the importance technology as one of main critical success factor. To sum up, the suggestion of this relationship is consistent with the predicted hypothesis (from the survey and past studies). This suggests and contributes that Saudi telecom companies should pay more attention to technology to be able to achieve CRM success and meet their expectation.

The empirical evidence has proved that there is a positive relationship between top management support and CRM success system registered the third greatest and significant standardized beta coefficient, indicating $31.8 \%$ top management positively increase the success of CRM. The 
results have reached the findings of similar studies in CRM success, which indicate the positive relationship between top management and CRM success such as the studies done by [4], [12], [8]. The follow-up interviews findings are consistent and confirm with the survey study suggestion as well as the previous studies that top management support has the positive relationship with CRM success.

The empirical evidence has proved that there is a positive relationship between CRM vision and CRM success system registered the fourth greatest and significant standardized beta coefficient, indicating $23.2 \% \mathrm{CRM}$ vision positively increase the success of CRM. The results tend to agree with the finding of studies by [4], [21], [8]. Moreover, the follow-up interviews findings are consistent and confirm with the survey study suggestion as well as the previous studies that CRM vision has a positive relationship with CRM success.

Re-engineering and integration process an important variable associated with CRM success. Hence, re-engineering and integration process has a significant positive and direct associated with successful CRM system registered the fifth greatest and significant standardized beta coefficient, indicating 21.9\%.The results have reached the findings of similar studies in CRM success, which indicate the positive relationship between Re-engineering and integration process and CRM success such as the studies done by [7], [20], [21]. In addition, these findings agree with followup interviews done previously with top managers.

Regarding the result that training has a significant positive and directly associated with successful CRM system registered the sixth greatest and significant standardized beta coefficient, indicating $20.3 \%$ training positively increase the success of CRM. Furthermore, the participants of the follow-up interviews enhance the importance training as one of main critical success factor. To sum up, the suggestion of this relationship is consistent with the predicted hypothesis (from the survey).

Regarding the result of the rewarding system has a significant positive and direct associated with successful CRM system registered the seven greatest and significant standardized beta coefficient, indicating $20.1 \%$ rewarding system positively increase the success of CRM. The results have reached the findings of similar studies in CRM success, which indicate the positive relationship between reward system and CRM success such as the studies done by [4], [20], [21]. In addition, the participants of the follow-up interviews confirm and agree with survey's findings as well as past studies.

\section{Conclusions}

Studies and researches show evidence on how CRM system might be an excessive benefit to profitability, improving customer satisfaction as well as customer loyalty. This could be applicable and appropriate to a wide range of sectors and fields; the telecommunication sector considered one of those sectors that could benefit from the adoption of CRM system greatly if it is implemented properly. Several researchers have identified and determined CSFs but few of them combine all these elements together. For that aim, the presented study could be considered quite important. The development of research model that called maturity successful CRM implementation (MSCRMI) model. The MSCRMI model presents CSFs and their relationships with CRM success such as the relationship between CRM success and KM, or between CRM success and technology. Though no one integrates these factors together into one model. The presented MSCRMI model contains seven factors and no one did the combination of these seven factors before. Furthermore, according to the research findings if the companies use this model it will increase the CRM success about $65.1 \%$. 
Further, many studies reported the factors that led to CRM success but did not prioritize them. Considering these gaps in the literature, the present study identified the main CSFs and prioritized their importance. Identification and prioritization of CSFs should allow the company to concentrate more resources on the most important factors, which in turn should lead to more success.

There also is a shortage of the literature regarding the implementation of CRM programs specifically in Saudi Arabia, especially in the telecom sector, and those studies that are available do not explore the reasons underlying CRM system success and failure. Given Saudi Arabia's advancing economic and technological status, a high frequency of CRM system failure might be expected, and failure incidence might accelerate as further development occurs. The current study is designed to help fill the gap in understanding regarding reasons for systems success and failure by exploring the main factors that contribute to CRM system success in Saudi Arabia.

\section{Suggestion For Future RESEARCH}

The sample of this study focused on the middle region of Saudi Arabia. However, future research should investigate the model in a different setting in Saudi Arabia, such as in the northern region. Therefore, more research needs to be done on these areas to measure and investigate international employees' satisfaction and loyalty in different countries.

\section{ACKNOWLEDGEMENTS}

The authors would like to thank everyone, just everyone!

\section{REFERENCES}

[1] K. C. Laudon, J. P. Laudon, and M. E. Brabston, Management information systems, Arab World., vol. 8. England: Pearson Education Limited (Verlag), 2013.

[2] S. Chakravorti, "Customer relationship management: A content analysis of issues and best practices," Florida International University PHD Theses, 2006.

[3] A. R. Zablah, D. N. Bellenger, and W. J. Johnston, "Customer relationship management implementation gaps,” J. Pers. Sell. Sales Manag., vol. 24, no. 4, pp. 279-295, 2004.

[4] A. Garrido-Moreno and A. Padilla-Meléndez, "Analyzing the impact of knowledge management on CRM success: The mediating effects of organizational factors,” Int. J. Inf. Manage., vol. 31, no. 5, pp. 437-444, 2011.

[5] A. Lindgreen, "The design, implementation and monitoring of a CRM programme: a case study," Mark. Intell. Plan., vol. 22, no. 2, pp. 160-186, 2004.

[6] S. Al-Hudhaif, "The Critical Success Factors for Implementation of Customer Relationship Management in the Banking Sector of Saudi Arabia," J. Glob. Bus. Manag., vol. 7, no. 1, pp. 1-7, 2011.

[7] A. Payne and P. Frow, "A strategic framework for customer relationship management," J. Mark., vol. 69, no. 4, pp. 167-176, 2005.

[8] L. Y. M. Sin, A. C. B. Tse, and F. H. K. Yim, "CRM: conceptualization and scale development," Eur. J. Mark., vol. 39, no. 11/12, pp. 1264-1290, 2005.

[9] J. U. Becker, G. Greve, and S. Albers, "The impact of technological and organizational implementation of CRM on customer acquisition, maintenance, and retention,” Int. J. Res. Mark., vol. 26, no. 3, pp. 207-215, Sep. 2009.

[10]L. E. Mendoza, A. Marius, M. Pérez, and A. C. Grimán, "Critical success factors for a customer relationship management strategy,” Inf. Softw. Technol., vol. 49, no. 8, pp. 913-945, Aug. 2007.

[11]I. Gordon, Managing the New Customer Relationship: Strategies to Engage the Social Customer and Build Lasting Value, First Ed. Mississauga, Ontario: John Wiley \& Sons, 2013.

[12]A. Croteau and P. Li, "Critical success factors of CRM technological initiatives," Can. J. Adm. Sci. Can. des Sci. l’Administration, vol. 20, no. 1, pp. 21-34, 2003. 
[13]J. Esteves and J. Pastor-Collado, "Analysis of critical success factors relevance along SAP implementation phases," in Proceedings of Americas Conference on Information Systems (AMCIS), 2001, pp. 1119-1125.

[14]M. Alavi and D. E. Leidner, "Review: Knowledge management and knowledge management systems: Conceptual foundations and research issues," MIS Q., vol. 25, no. 1, pp. 107-136, 2001.

[15]R. P. Uit Beijerse, "Questions in knowledge management: defining and conceptualising a phenomenon,” J. Knowl. Manag., vol. 3, no. 2, pp. 94-110, 1999.

[16]A. A. Khaligh, A. Miremadi, and M. Aminilari, "The impact of eCRM on loyalty and retention of customers in Iranian telecommunication sector,” Int. J. Bus. Manag., vol. 7, no. 2, pp. 150-162, 2012.

[17]A. Lindgreen, R. Palmer, J. Vanhamme, and J. Wouters, "A relationship-management assessment tool: Questioning, identifying, and prioritizing critical aspects of customer relationships," Ind. Mark. Manag., vol. 35, no. 1, pp. 57-71, Jan. 2006.

[18]J. Radcliffe, "Eight building blocks of CRM: A framework for success," in Gartner research, 2001 , vol. 13, pp. $1-4$.

[19]A. Keramati, H. Samadi, S. Nazari-Shirkouhi, and N. Askari, "Identifying and prioritising critical success factors for CRM implementation: a case study,” Int. J. Electron. Cust. Relatsh. Manag., vol. 6, no. 3-4, pp. 235-256, 2012.

[20]R. J. Ocker and S. Mudambi, "Assessing the readiness of firms for CRM: a literature review and research model," in System Sciences, 2003. Proceedings of the 36th Annual Hawaii International Conference on, 2003, p. 10-pp.

[21]I. J. Chen and K. Popovich, "Understanding customer relationship management (CRM): People, process and technology,” Bus. Process Manag. J., vol. 9, no. 5, pp. 672-688, 2003.

[22]T. S. H. Teo, P. Devadoss, and S. L. Pan, "Towards a holistic perspective of customer relationship management (CRM) implementation: A case study of the Housing and Development Board, Singapore,” Decis. Support Syst., vol. 42, no. 3, pp. 1613-1627, Dec. 2006.

[23]R. C. Ford and W. A. Randolph, "Cross-functional structures: A review and integration of matrix organization and project management," J. Manage., vol. 18, no. 2, pp. 267-294, 1992.

[24]W. L. Neuman, Social research methods: Qualitative and quantitative approaches, 7th ed. Boston: Pearson, 2014.

[25]A. Tashakkori and C. Teddlie, Handbook of mixed methods in social \& behavioral research, Second Ed. United States of America: Sage, 2010.

[26]J. F. Hair, W. C. Black, B. J. Babin, R. E. Anderson, and R. L. Tatham, "Multivariate data analysis (Vol. 6).” Upper Saddle River, NJ: Pearson Prentice Hall, 2006.

\section{Authors}

Sara AL-Rashed is lecturer department Information system with AL-Imam Muhammad bn Saud Islamic University, Riyadh, Saudi Areabia. Her research interests include customer relationship management, system analysis, data mining.

Riyad Almakki Skilled in Business Process, Analytical Skills, Enterprise Architecture, Lecturing, and Databases. Strong quality assurance professional with a $\mathrm{PhD}$ focused in Information Systems from Manchester University 